다 I프 IU 소

Jurnal Gentiaras Manajemen dan Akuntasi

Laman Jurnal: jurnal.gentiaras.ac.id/index.php/Gema/index

ISSN : 2086-9592 (p) , 2721-5490 (e)

\title{
Pengaruh Biaya Kualitas Terhadap Minimalisasi Produk Rusak pada Produk Home Industri Pembuatan Peyek Kacang
}

\author{
Rina Milyati Yuniastuti \\ STIE Prasetiya Mandiri Lampung, Indonesia \\ *email: rinamilyati@gmail.com
}

\begin{tabular}{|c|c|}
\hline$A R T I C L E \quad I N F O$ & $A B S T R A C T$ \\
\hline $\begin{array}{l}\text { Artikel History: } \\
\text { Received:December 27, } 2020 \\
\text { Revised: January 30, } 2021 \\
\text { Published:February 9, } 2021\end{array}$ & $\begin{array}{l}\text { Research with the object of the home industry is the manufacture of peyek kacang which is a } \\
\text { traditional food. This study aims to determine the influence of quality costs (prevention costs } \\
\text { and appraisal costs) on damaged products. The data analysis method used in this research is } \\
\text { descriptive analysis and quantitative analysis. Descriptive analysis to describe the state of the } \\
\text { variables in the study while for quantitative analysis with multiple linear regression analysis } \\
\text { and hypothesis testing. The results of this study indicate that simultaneously or the F test there } \\
\text { is a significant influence between the cost of prevention and the cost of assessing damaged } \\
\text { products in home products. Peyek kacang industry with a contribution of } 11.8 \% \text { with a } \\
\text { significant test value F count }=-0.46>F \text { table }=-214.6 . \text { Partially there is a significant effect } \\
\text { on the cost of prevention of damaged products, where the significant value of the t test }=- \\
0.553>t \text { table }=-1.27 \text { and there is also a significant effect of the cost of assessing damaged } \\
\text { products, where the significant value of the t test }=-0.652>t \text { table }=-1.27 \text { with an error rate } \\
\text { of } 5 \% \text {. }\end{array}$ \\
\hline I N F O A R T I K E L & A B S T R A K \\
\hline $\begin{array}{l}\text { Riwayat Artikel: } \\
\text { Diterima: } 27 \text { Desember } 2020 \\
\text { Direvisi: } 30 \text { Januari } 2021 \\
\text { Dipublikasikan: } 9 \text { Februari } 2021\end{array}$ & $\begin{array}{l}\text { Penelitian dengan objek pada home indutri yaitu pembuatan peyek kacang yang merupakan } \\
\text { makanan tradisional. Penelitian ini bertujuan untuk mengetahui besarnya pengaruh biaya } \\
\text { kualitas ( Biaya pencegahan dan biaya penilaian) terhadap produk rusak. Metode analisis data } \\
\text { yang digunakan dalam penelitian ini adalah analisis deskriptif dan analisis kuantitatif. Analisis } \\
\text { deskriptif untuk menggambarkan keadaan variabel -variabel dalam penelitian sedangkan } \\
\text { untuk analisis kuantitatif dengan analisis regresi linier berganda serta uji hipotesis. Dari hasil } \\
\text { penelitian ini menunjukkan bahwa secara simultan atau uji } \mathrm{F} \text { terdapat pengaruh yang } \\
\text { signifikansi antara biaya pencegahan dan biaya penilaian terhadap produk rusak pada produk } \\
\text { home industri peyek kacang dengan kontribusi sebesar } 11,8 \% \text { dengan nilai uji signifikan } \mathrm{F} \\
\text { hitung }=-0,46>\mathrm{F} \text { tabel }=-214,6 \text {. Secara parsial terdapat pengaruh yang signifikan biaya } \\
\text { pencegahan terhadap produk rusak, dimana nilai signifikan Uji t hitung }=-0,553>\mathrm{t} \text { tabel }=- \\
1,27 \text { dan juga terdapat pengaruh yang signifikan biaya penilaian terhadap produk rusak } \\
\text {,dimana nilai signifikan Uji thitung }=-0,652>\mathrm{t} \text { tabel }=-1,27 \text { dengan tingkat kesalahan } 5 \% \text {. }\end{array}$ \\
\hline
\end{tabular}




\section{PENDAHULUAN}

Suatu usaha atau bisnis yang bergerak di bidang barang konsumsi tentukan tidak terlepas dari produk yang rusak atau gagal. Produk rusak atau produk gagal/ yang tidak layak untuk dijual merupakan produk yang memang bisa terjadi di barang konsumsi. Pada banyaknya produk yang rusak atau gagal jual maka akan berpengaruh terhadap kualitas produk tersebut.Ini juga menyebabkan suatu usaha atau bisnis mengalami kerugian akibat banyaknya produk yang rusak.Maka dari itu usaha atau perusahaan harus sedapat mungkin meminimalisasi kerusakan produk atau kegagalan produk.Untuk dapat meminimalisasi kerusakan produk maka harus dijaga cara mengolahan atau teknik pengolahan produk sehingga kualitas produk terjamin.Memang banyak kendala dalam menjaga kualitas produk agar perusahaan tidak menderita kerugian yang besar. Dengan kualitas produk yang terjaga maka perusahaan dapat menekan jumlah produk yang rusak seminimal mungkin, sehingga perusahaan dapat mengendalikan jumlah produk rusak yaitu dengan mengeluarkan biaya kualitas yang terdiri dari biaya pencegahan dan biaya penilaian.Pada dasarnya biaya kualitas yang dikeluarkan untuk mengurangi produk dari kerusakan. Hal ini terjadi pada objek penelitian home industri pembuatan peyek kacang yang berlokasi di Bandar Lampung. Kerusakan produk yang terjadi semakin meningkat dari hari ke hari maka dapat berdampak pada peningkatan harga pokok produksi produk. Dan ini juga dapat berdampak buruk pada tingkat persaingan di bisnis home industri peyek kacang. Dampak semakin besar jika produk rusak dialami oleh home industri yang dengan modal kecil dapat berakibat terjadinya gulung tikar usaha tersebut.Dari dampak inilah maka kualitas produk perlu dijaga.

Menurut Mulyadi (2009:102) Produk rusak adalah produk yang tidak memenuhi standar mutu yang telah ditetapkan yang secara ekonomis tidak dapat diperbaharui menjadi produk yang baik. Produk rusak dapat dihitung dengan menggunakan 4 cara .Menurut Sutrisno (2001:210) ke 4 cara tersebut adalah Produk bersifat normal laku dijual,produk bersifat normal tidak laku dijual,bersifat abnormal laku dijual dan abnormal tidak laku dijual. Sehingga seminimal mungkin bagi pelaku bisnis produk rusak jangan sampai meningkat.Untuk itu suatu produk harus dapat memenuhi kualitasnya.

Kualitas merupakan kepuasan konsumen/pelanggan.Adapun kualitas adalah ukuran relative dari kebaikan/goodness. Dengan menjaga suatu kualitas produk atau meminimalisasi produk rusak maka akan meningkatkan keuntungan/laba dalam suatu bisnis atau usaha.Dan akan juga meminimalisir kerugian yang besar.Dengan menjaga kualitas produk maka akan meminimalkan biaya yang dikeluarkan perusahaan . 
Menurut Heizer dan Render (2015:244), kualitas adalah keseluruhan fitur dan karakteristik sebuah barang atau jasa yang menggunakan kemampuannya untuk memenuhi kebutuhan yang dijanjikan dan tersirat. Sedangkan Menurut Temy \& Ahalik (2014:35), biaya kualitas (cost of quality) adalah biaya yang dikeluarkan perusahaan dalam rangka meningkatkan kualitas produknya. Dan menurut Siregar dkk (2013:288), biaya kualitas (cost of quality) adalah biaya yang terjadi atau mungkin terjadi karena adanya kualitas yang rendah. Untuk kualitas produk yang rendah maka akan menurunkan omset usaha,ini terjadi karena kualitas produk tidak terjamin dengan baik.Biaya yang dikeluarkan untuk meningkatkan kualitas barang disebut dengan biaya kualitas. Biaya kualitas dapat dikelompokkan menjadi empat golongan yaitu biaya pencegahan, biaya deteksi/penilaian, biaya kegagalan internal dan biaya kegagalan eksternal (Blocher et al. 2012:487).

Dalam penelitian ini biaya kualitas menggunakan biaya pencegahan dan biaya penilaian. Jika biaya pencegahan dan biaya penilaian meningkat berarti menunjukkan jumlah unit produk rusak menurun dan sebaliknya jika biaya pencegahan dan biaya penilaian menurun menunjukkan jumlah unit produk rusak meningkat. Di lain pihak, biaya kegagalan internal dan biaya kegagalan ekternal naik jika jumlah unit poduk rusak meningkat dan sebaliknya biaya kegagalan internal dan biaya kegagalan ekternal turun jika jumlah unit produk rusak turun. Setelah biaya kualitas diidentifikasikan dan disusun dengan kategori pengelompokannya, maka biaya kualitas dapat dianalisis untuk dijadikan sebagai dasar dalam pengambilan keputusan yang sesuai dalam penelitian ini adalah biaya pencegahan dan biaya penilaian terhadap minimalisasi produk rusak. Dasar yang diseleksi tersebut dapat bervariasi, tergantung pada produk dan jenis pabrik untuk suatu bisnis tertentu .

\section{METODE PENELITIAN}

\section{Jenis Penelitian}

Jenis penelitian yang dilakukan penulis adalah jenis penelitian yang menggunakan metode analisis deskriptif kuantitatif .Penelitian dengan metode deskriptif kuantitatif ini merupakan suatu penelitian yang mendeskriptifkan dan menginterprestasikan suatu data yang telah terkumpul sebagaimana adanya.

\section{Tempat Penelitian}

Tempat penelitian dilakukan di home industri pembuatan peyek kacang. Home industri ini bernama peyek kacang Minanti yang ada di Teluk Betung Selatan Bandar Lampung pada tahun 2019. 


\section{Populasi dan Sampel}

Populasi dari penelitian ini adalah seluruh data produk peyek kacang. Dan metode yang digunakan dalam penelitian ini adalah metode pruposive sampling. Adapun pertimbanganpertimbangan yang digunakan adalah Home Industri pembuatan peyek kacang Minanti, Laporan keuangan yang menyajikan kas dan setara kas, utang lancar, total utang, total aset, penjualan, serta laba bersih, dan Penelitian untuk data keuangan tahun 2018 dan 2019.

\section{Variabel Penelitian}

Variabel dalam penelitian ini ada 2 yaitu:

1. Biaya Kualitas (X) yang meliputi:

a. Biaya Pencegahan $\left(\mathrm{X}_{1}\right)$

Yaitu biaya yang terjadi untuk mencegah kualitas yang jelek pada produk atau jasa yang akan dihasilkan. Biaya pencegahan dalam penelitian ini adalah biaya pencegahan yang dikeluarkan pada perusahaan selama tahun 2018-2019. Indikator dari biaya pencegahan adalah biaya perencanaan dan pengawasan produk, dan biaya pemeliharaan mesin

b. Biaya Penilaian $\left(\mathrm{X}_{2}\right)$

Yaitu biaya yang terjadi untuk menentukanapakah produk atau jasa telah sesuai dengan persyaratandan kebutuhan pelanggan. Biaya penilaian dalam penelitian ini adalah biaya penilaian yang dikeluarkan pada perusahaan selama tahun 2018-2019. Indikator dari biaya penilaian adalah biaya pengujian bahan baku, dan biaya inspeksi proses produksi.

\section{Produk Rusak (Y)}

Variabel dependent dalam penelitian ini adalah produk rusak dari 2018-2019.Produk rusak adalah produk yang tidak sesuai dengan standar mutu yang telah ditetapkan secara ekonomis,tidak dapat diperbaharui menjadi produk yang baik.(Mulyadi,2009:102).

\section{Teknik Pengumpulan Data}

Dalam penelitian ini penulis dalam pengumpulan data menggunakan metode dokumentasi yaitu dengan informasi yang diperoleh dari pengumpulan data secara tertulis dimana penulis meminta data-data yang terkait dengan penelitian ini. Selain itu pengumpulan dan menggunakan metode wawancara yang dilakukan dengan komunikasi langsung pada bagian produksi untuk mendapatkan informasi yang berkaitan dengan penelitian ini. 


\section{Teknik Analisis Data}

Teknik analisis data adalah suatu metode yang digunakan untuk mengolah data hasil penelitian guna memperoleh suatu kesimpulan.Metode analisis data yang digunakan dalam penelitian ini adalah analisis deskriptif dan analisis kuantitatif.

\section{Analisis Regresi Linier Berganda}

Penelitian ini menggunakan analsisi regresi linier berganda (Multiple Regression Analysis).Analisis regresi linier berganda ini digunakan untuk menguji pengaruh biaya pencegahan dan biaya penilaian terhadap minimalisasi produk rusak.Formulasi persamaan regresi linier berganda adalah sebagai berikut:

$\mathrm{Y}=\mathrm{a}+\mathrm{b}_{1} \mathrm{X}_{1}+\mathrm{b}_{2} \mathrm{X}_{2}$

Persamaan di atas dijelaskan dengan $y$ merupakan produk rusak, $a$ merupakan bilangan konstanta, $X_{1}$ merupakan biaya pencegahan, $X_{2}$ merupakan biaya penilaian, dan $\mathrm{b}_{1}, \mathrm{~b}_{2}$ adalah parameter yang diestimasi untuk $\mathrm{X}_{1}$ dan $\mathrm{X}_{2}$.

\section{Pengujian Hipotesis}

1). Uji Simultan atau Uji F-tes

Menguji apakah semua variabel independent mempunyai pengaruh yang secara bersamasama terhadap variabel dependent. Langkah-langkah uji f adalah penentuan hipotesis, penentuan tingkat signifikasnsi, penentukan $\mathrm{F}_{\text {hitung, }}$, penentukan $\mathrm{F}_{\text {tabel, }}$, dan pengkriteria pengujian.

2). Uji Parsial atau Uji T -tes

Uji hipotesis dengan uji t-hitung digunakan untuk menguji koefisien regresi variabel independent.Langkah-langkah uji t adalah penentukan hipotesis, penentukan tingkat signifikansi, penentukan $\mathrm{T}_{\text {hitung, }}$ penentukan $\mathrm{T}_{\text {tabel, }}$ dan pengkriteria pengujian.

\section{HASIL DAN PEMBAHASAN}

\section{Deskripsi Variabel Penelitian}

Hasil penelitian dan pembahasan yang meliputi analisis kuantitatif berupa analisis data yang terdiri dari analisis data keuangan,pengujian pengaruh antara variabel independent dan variabel dependent ,pengujian hipotesis penelitian dan pembahasan. Variabel independent (X) dalam penelitian ini adalah biaya pencegahan (X1) dan biaya penilaian (X2).Pada Home industri peyek kacang Minanti untuk biaya biaya yang terkait dengan peningkatan kualitas produk belum tersusun 
dengan baik dan belum masuk ke dalam laporan biaya kualitas.Jadi untuk biaya pencegahan dan biaya penilaian dalam home industri ini antara lain biaya perencanaan produk, biaya pemeliharan alat, biaya pendistribusian produk, biaya pembuatan produk, biaya bahan baku produk. Sedangkan untuk variabel dependent yang dimaksud dengan variabel $\mathrm{Y}$ dalam penelitian ini adalah produk rusak. Variabel dependent merupakan variabel yang mempunyai hubungan dengan biaya kualitas atau variabel bebas. Dalam Penelitian ini jumlah produk rusak pada peyek kacang dari tahun 2018 2019 disajikan dalam bentuk laporan bulanan dan dinyatakan dengan satuan unit.

Penelitian ini mempunyai tujuan untuk mengetahui Pengaruh biaya kualitas (biaya pencegahan dan biaya penilaian) sebagai variabel independent terhadap minimalisasi produk rusak sebagai variabel dependent pada produk peyek kacang Minanti. Dalam variabel Independent dan variabel dependent, data yang diperoleh dengan cara meminta data laporan keuangan tahun 20182019 dan melakukan wawancara kepada pemilik usaha peyek kacang Minanti dan data ini kemudian dianalisis dengan regresi linier berganda dan diuji dengan $\mathrm{F}$ test dan uji $\mathrm{T}$ test.

Tabel 1 Total Rata- rata Biaya Kualitas ( biaya pencegahan dan biaya penilaian) dan Produk Rusak Tahun

\begin{tabular}{|c|c|c|c|}
\hline \multicolumn{4}{|c|}{ 2018-2019 } \\
\hline Tahun & Biaya pencegahan (X1) & Biaya penilaian (X2) & Produk rusak ( Y) \\
\hline 2018 & 5,14 & 5,10 & 0,22 \\
\hline 2019 & 5,50 & 5,30 & 0,35 \\
\hline
\end{tabular}

Sumber: Data olahan

Dari tabel diatas dijelaskan bahwa tahun pada tahun 2019 proporsi kerusakan produk ada sebesar 0,35 \%.Dengan rata -rata proporsi untuk biaya pencegahan dari tahun 2018 ke 2019 menjadi naik 0,36\%, untuk proporsi biaya penilaian juga mengalami kenaikan menjadi 0,20\% sehingga produk yang rusak mengalami kenaikan menjadi $0,13 \%$.

\section{Uji Regresi Linier Berganda}

Uji Regresi digunakan untuk mengetahui pengaruh variabel independent $(\mathrm{X})$ terhadap variabel dependent $(\mathrm{Y})$; Penelitian ini penulis menggunakan uji regresi linier berganda dengan variabel independent $(\mathrm{X})$ yaitu biaya kualitas yang dikelompokkan menjadi biaya pencegahan $\left(\mathrm{X}_{1}\right)$ dan biaya penilaian $\left(\mathrm{X}_{2}\right)$ terhadap variabel dependent $(\mathrm{Y})$ yaitu produk rusak.Perhitungan menggunakan SPSS 16.00 for windows diperoleh hasil sebagai berikut: 
Tabel 2. Ringkasan Hasil PerhitunganKomputer dengan Program SPSS

\begin{tabular}{ll}
\hline \multicolumn{1}{c}{ Uraian } & \multicolumn{1}{c}{ Nilai } \\
\hline Konstanta & 24560,235 \\
Koefisien regresi biaya pencegahan & $-0,0011$ \\
Keofisien regresi biaya penilaian & $-0,0003$ \\
$\mathrm{~F}$ hitung & $-0,46$ \\
$\mathrm{R}^{2}$ & 0.212 \\
Adjusted $\mathrm{R}^{2}$ & 0,118 \\
t hitung variabel biaya pencegahan & $-0,553$ \\
t hitung variabel biaya penilaian & $-0,652$ \\
\hline
\end{tabular}

Sumber: Data olahan

Dari tabel diatas maka diperoleh persamaan regresi linier berganda sebagai berikut:

$$
Y=24560,235-0,0011 X_{1}-0,0003 X_{2}
$$

$\mathrm{a}=24560,235$ berarti jika semua variabel independent (X) sama dengan nol maka produk rusak (Y) sebesar 24560,235; b1 =-0,0011 berarti jika biaya pencegahan $\left(\mathrm{X}_{1}\right)$ naik sebesar Rp.1,- sedangkan variabel lainnya konstan maka produk rusak (Y) akan turun sebesar 0,0011; b2 =-0,0003 berarti jika biaya penilaian $\left(\mathrm{X}_{2}\right)$ naik sebesar Rp.1,- sedangkan variabel lainnya konstan maka produk rusak (Y) akan turun sebesar 0,0003.

\section{Uji t atau Uji parsial}

Untuk penjelasan mengenai uji hipotesis secara parsial pada pengaruh biaya pencegahan dan biaya penilaian terhadap minimalisasi produk rusak, yaitu Terima Ho jika $\mathrm{T}$ hitung $\leq \mathrm{T}$ tabel : Tidak terdapat pengaruh secara parsial biaya kualitas terhadap minimalisasi produk rusak; Tolak Ho jika $\mathrm{T}$ hitung $>\mathrm{T}$ tabel : Terdapat pengaruh secara parsial biaya kualitas terhadap minimalisasi produk rusak.

Hasil analisis regresi menunjukkan bahwa biaya pencegahan dari uji t diperoleh $\mathrm{T}$ hitung =0,553> T tabel $=-1,27$ maka Ho ditolak, sehingga dapat disimpulkan bahwa $\mathrm{H} 1$ terdapat pengaruh secara parsial biaya pencegahan terhadap produk rusak dengan tingkat kesalahan 5\%. Hasil analisis regresi menunjukkan bahwa biaya penilaian dari uji t diperoleh $\mathrm{T}$ hitung $=-0,652>\mathrm{T}$ tabel $=-1,27$ maka Ho ditolak, sehingga dapat disimpulkan bahwa $\mathrm{H} 2$ terdapat pengaruh secara parsial biaya pencegahan terhadap produk rusak dengan tingkat kesalahan $5 \%$.

\section{Uji F atau Uji simultan}

Untuk penjelasan mengenai hipotesis secara simultan tentang pengaruh biaya kualitas (biaya pencagahan dan biaya penilaian) terhadap produk rusak, yaitu Terima Ho jika $F$ hitung $\leq F$ tabel : Tidak terdapat pengaruh secara simultan antara biaya pencegahan dan biaya penilaian terhadap 
produk rusak; Tolak Ho jika F hitung $\geq$ F tabel : Terdapat pengaruh secara simultan antara biaya pencegahan dan biaya penilaian terhadap produk rusak.

Hasil analisis regresi menunjukkan bahwa dari dua variabel independent/variabel bebas yaitu biaya pencegahan dan biaya penilaian hasil Uji $\mathrm{F}$ diperoleh $\mathrm{F}$ hitung $=-0,46>\mathrm{F}$ tabel $=-214,6$ sehingga dapat disimpulkan bahwa Ho ditolak dan $\mathrm{H} 1$ diterima yang berarti terdapat pengaruh yang signifikan secara simultan antara biaya pencegahan dan biaya penialain terhadap produk rusak.

Dari hasil analisis regresi besarnya sumbangan yang dikeluarkan niaya kualitas terhadap produk rusak ditunjukkan oleh koefisien determinan sebesar 0,118 atau sebesar $11,8 \%$. Jadi dapat dikatakan bahwa nilai sebesar 11,8 \% perubahan produk rusak disebabkan oleh perubahan biaya pencegahan dan biaya penilaian.Sedangkan sisanya sebesar 88,2\% dipengaruhi oleh variabel lain yang tidak termasuk variabel dalam pembahasan penelitian ini.

\section{KESIMPULAN}

Analisis data dan pembahasan maka dapat ditarik kesimpulan salah satunya adalah secara parsial terdapat pengaruh yang signifikan antara biaya pencegahan terhadap produk rusak dengan nilai uji signifikan uji t hitung $=-0,553>\mathrm{t}$ tabel $=-1,27$ dengan tingkat kesalahan $5 \%$. Selain itu, secara parsial terdapat pengaruh yang signifikan antara biaya penilaian terhadap produk rusak dengan nilai uji signifikan uji t hitung $=-0,652>\mathrm{t}$ tabel=-1, 27 dengan tingkat kesalahan 5\%. Dan secara simultan terdapat pengaruh yang signifikan antara biaya pencegahan dan biaya penilaian terhadap produk rusak pada produk home industri peyek kacang Miranti dengan kontribusi sebesar $11,8 \%$ dengan uji signifikan $\mathrm{F}$ hitung $=-0,46$ dengan tingkat kesalahan $5 \%$.

Saran penulis berdasarkan hasil penelitian yang juga merupakan peluang penelitian selanjutnya adalah diharapkan bisa mengembangkan penelitian kepada objek dengan sampel yang lebih signifikan karena pada penelitian ini hanya sebatas pada home industri. Selain itu, peneliti selanjutnya untuk menilai biaya produk rusak yang lainnya karena Penelitian ini hanya pada biaya pencegahan dan biaya penilaian. Data penelitian pun perlu dipertimbangkan untuk menggunakan data yang lebih banyak tahun pengamatannya agar hasil lebih akurat.

\section{DAFTAR PUSTAKA}

Blocher,Edward j.,kung H Chen dan Thomas W. Lin .2012.Manajemen biaya dengan tekanan stratejik. Terjemahan A.Susty Ambarriani.Salemba Empat.Jakarta

Bustami,Bastian Dan Nurlela .2009.Akuntansi Biaya.Edisi Pertama.Mitra Wacana Media.Jakarta.

Carter..Akuntansi Biaya.2014. Edisi 14.Salemba Empat.Jakarta

Fahmi ,Irham.Manajemen Produksi dan Operasi .Edisi 1 .Alfabeta..Bandung. 
Fahmi, Irham. Analisis Laporan Keuangan, Edisi Pertama. Alfabeta. Bandung.

Hasanuh, Nanu. 2011. Akuntansi Dasar: Teori dan Praktik, Edisi Pertama. Mitra Wacana Media. Jakarta.

Heizer, Render. 2015. Manajemen Operasi.Edisi 11. Salemba Empat.Jakarta.

Herawati,Shinta D dan Indri C Lestari.2012.Tinjauan atas Perlakuan Akuntansi untuk produk cacat dan produk Rusak pada PT.Indo Pasifik.Jurnal Nasional Akuntansi dan Bisnis.ISSN:25523936.Vol.2 (Maret).No.2:570-583.

Hery. 2015. Analisis Laporan Keuangan, PT Buku Seru. Cet 1. Yogyakarta.

Hery. 2015. Pengantar Akuntansi Compehensive Edition "Lengkap dengan Kumpulan Soal dan Solusinya”, PT Grasindo. Jakarta.

Kasmir. 2014. Analisis Laporan Keuangan, Edisi Pertama (Revisi). PT RajaGrafindo Persada. Jakarta.

Milyati,Rina .2020.Pengaruh Biaya Kualitas terhadap minimalisasi produk rusak pada produk home industri pembuatan peyek kacang, Vol.12 No.1.Jurnal Gema ,Jurnal Gentiaras manajemen dan Akuntansi.

Mulyadi. 2009.Akuntansi Biaya.Yogyakarta: YKPN

Munawir. 2010. Analisa Laporan Keuangan, Edisi Keempat. Liberty. Yogyakarta.

Siregar dkk.2013.Akuntansi Biaya.Salemba Empat.Jakarta

Sugiyono.2012.Metode Penelitian Kuantitatif,Kualitatif dan $R \& D$. Alfabeta: Bandung.

Sujarweni.2015.Akuntansi Biaya.Pustaka Baru Press.Surakarta.

Sutrisno.2001.Manajemen Keuangan.Edisi Revisi .Ekonisia.

Temy,Ahalik.2014.Akuntansi Biaya Dan Manajemen. Bhuana Ilmu Populer. 